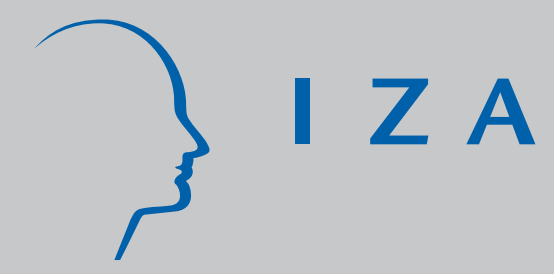

IZA DP No. 859

Loafing or Learning? The Demand for Informal Education

René Fahr

August 2003 


\title{
Loafing or Learning? The Demand for Informal Education
}

\author{
René Fahr \\ University of Bonn \\ and IZA Bonn
}

Discussion Paper No. 859
August 2003

IZA

P.O. Box 7240

D-53072 Bonn

Germany

Tel.: +49-228-3894-0

Fax: +49-228-3894-210

Email: iza@iza.org

This Discussion Paper is issued within the framework of IZA's research area The Future of Labor. Any opinions expressed here are those of the author(s) and not those of the institute. Research disseminated by IZA may include views on policy, but the institute itself takes no institutional policy positions.

The Institute for the Study of Labor (IZA) in Bonn is a local and virtual international research center and a place of communication between science, politics and business. IZA is an independent, nonprofit limited liability company (Gesellschaft mit beschränkter Haftung) supported by Deutsche Post World Net. The center is associated with the University of Bonn and offers a stimulating research environment through its research networks, research support, and visitors and doctoral programs. IZA engages in (i) original and internationally competitive research in all fields of labor economics, (ii) development of policy concepts, and (iii) dissemination of research results and concepts to the interested public. The current research program deals with (1) mobility and flexibility of labor, (2) internationalization of labor markets, (3) welfare state and labor market, (4) labor markets in transition countries, (5) the future of labor, (6) evaluation of labor market policies and projects and (7) general labor economics.

IZA Discussion Papers often represent preliminary work and are circulated to encourage discussion. Citation of such a paper should account for its provisional character. A revised version may be available on the IZA website (www.iza.org) or directly from the author. 
IZA Discussion Paper No. 859

August 2003

\begin{abstract}

\section{Loafing or Learning? The Demand for Informal Education*}

Using detailed time use data for Germany a positive correlation is found between the level of schooling education and time investments in informal education. Two hypotheses explain this observation: (1) highly educated people have higher opportunity costs of their leisure time and thus prefer leisure activities which add to their market productivity (wage effect) and (2) highly educated people have a preference for 'high quality' leisure (taste effect). The demand for informal education is derived in a household production model accounting for both explanations. An empirical investigation finds evidence for both effects with the taste effect being the more important effect. Highly educated people accumulate human capital through their specific leisure time use. This increases the skill-gap between higher and lower educated people.
\end{abstract}

JEL Classification: $\quad$ C24, D13, J22, J24

Keywords: informal education, lifelong learning, time allocation, household production, censored LAD

René Fahr

IZA

P.O. Box 7240

53072 Bonn

Germany

Tel.: +492283894 160

Fax: +492283894210

Email: fahr@iza.org

\footnotetext{
* I am indebted to Dan Hamermesh for encouragement, helpful hints, and very useful comments on earlier versions of this paper. I am grateful to Hielke Buddelmeyer, Arnauld Chevalier, Thomas Dohmen, Rob Euwals, Stephen Jenkins, Peter Kooreman, Steve Nickell, Wendelin Schnedler, Uwe Sunde and Frank Thierbach, as well as participants at the Conference of the International Network on the Economics of Time Use in St. Gerlach, the Netherlands, the Pre-Conference in Bonn, the ESPE 2002 in Bilbao, and at seminars at IZA and the University of Cologne for their very helpful comments. Financial support from DAAD and DFG is gratefully acknowledged.
} 


\section{Introduction}

According to the education ministers of the OECD member countries lifelong learning will be one of the most important characteristics of the working life of the future (see e.g. Johnston (1998)). While specialized competence depreciate very fast in terms of economic value, workers of all skill levels have to update their technical skills and enhance their general skills to keep pace with the continuous technological change and new job requirements (see e.g. Bartel and Sicherman, 1998, Gould, 2002). Formal education as provided by training courses during work-time accounts only for a small part of the required educational activities.

Economists currently try to identify determinants of labor market success other than observable formal degrees (see Bowles et al. (2001) for an overview). One important factor might be the specific use of leisure time by successful workers. Hence, rather than solely investigating the participation in work-related training courses during work-time, research should focus more on the educational character of certain leisure activities.

This study is a first approach to find out more about the diffusion of the informal forms of education while working in the labor market. The main concern will be to find out more about the determinants of time spent on informal education rather than the returns to these activities. The availability of detailed time use data allows to precisely select activities which we might think have an educational character. By using time use data we follow the small literature investigating the allocation of non-market time with data on individuals' time use. Kooreman and Kapteyn (1987) estimate the time allocation within the household between seven types of leisure categories with the 1975-1976 University of Michigan Time Use study. Biddle and Hamermesh (1990) estimate the demand for the non-market activity, sleep, using the same data set. To the knowledge of the author this is the first attempt to investigate questions of training and adult education with time use data. Moreover, we are able to show the robustness of our findings by providing results of a comparable investigation with survey data.

As we will see one of the main determinants of participation in informal adult learning and the amount of time spent on informal education is the level of schooling education. In this the determinants are comparable to the participation in other formal training and educational activities. Taking the level of education as exogenous we test two hypotheses which might explain a positive correlation between the level of schooling education and the time spent on informal education. On the one hand, this could simply reflect a wage effect in the sense that workers with a higher earnings potential prefer a leisure activity which adds to their productivity and has therefore the lowest opportunity costs. The alternative hypothesis claims that higher educated people simply have a different utility function including a taste for educational activities during their leisure time or a "love to learn". 
The next section will discuss our notion of informal education, shortly introduce the data used for this paper and establish the link between schooling education and informal adult learning in our data. In section 3 we formulate two hypotheses to explain the relation between schooling education and participation in informal education. A theoretical model encompasses these hypotheses and guides the further analysis. Section 4 provides the basic results for the demand for informal education and a detailed analysis to evaluate the relative importance of the taste and the wage effect after describing the empirical strategy and the sample selected for the estimates. Section 5 concludes.

\section{Definitions, Data, and First Insights}

\subsection{Informal Education in Our Data Sources}

This paper is concerned with informal education in contrast to formal forms of training like workplace training. To be more specific, we are interested in educational activities as part of daily leisure time and in informal education as a specific kind of lifelong learning. An educational activity should involve a certain human capital enhancing character which leads to higher wages or better employment probabilities in the future. One might argue the definition of informal education depends on the occupation and the hierarchical rank of the worker. While do-it-yourself activities might be human capital enhancing in the sense described above for workers in craft occupations, this might not be the case for members of other occupations. Therefore, we try to investigate activities of informal education which are human capital enhancing for a broad group of workers. One example of such an activity is reading non-fiction books, magazines and newspapers. ${ }^{1}$ Irrespective of the job one currently holds, this helps to enhance verbal skills and trains in learning something new.

In our main data source, the 1991/1992 German Time Use data we have very detailed information concerning the time use of household members older than 12 years in about 7200 German households for two consecutive days supplemented by information on the socio-economic background. ${ }^{2}$ Individuals report their activity in plain text in five-minute intervals ${ }^{3}$ and the activities were coded in 231 categories of time use by the Federal Statistical Office. This detailed information allows to collect in one variable all activi-

\footnotetext{
${ }^{1}$ This is in line with the definition of learning given by the National Institute of Adult Continuing Education (NIACE) in the UK. Among the activities which constitute learning in their view is "reading about something" (see Sargant et al. (1997)).

${ }^{2} \mathrm{~A}$ detailed description of the data can be found in Appendix B.

${ }^{3}$ Keeping a diary seems to be a very time consuming activity in itself; in fact, according to calculations by the author the average time spent on this activity is about 8 minutes in two days.
} 
ties which owe their informal character to the fact that they take place after work-time and serve only to a minor part the current job (INFOEDU2). A second definition of informal education (INFOEDU1) differs from the former mainly in the inclusion of all sorts of (non-fiction) reading activities. See Table A.1 in the Appendix for details.

In the two cross-sections of the Qualification and Career Survey data (Q and $\mathrm{C}$ data) for the years 1991/1992 and 1998/1999 we have information about different activities of formal and informal (occupation related) education within the period of five years prior to the date of the survey. Informal varieties of education are much more difficult to trace down than in the time use data. We investigate different educational activities which differ by the degree of formality. ${ }^{4}$ While informal educational activities are represented in this data set clearly not in an ideal way, one should keep in mind that these data serve as a robustness check for our findings with the time use data.

\subsection{Schooling Education and Informal Education}

A typical determinant of participation in training and learning during the adult life is the level of schooling education. ${ }^{5}$

Accordingly, Table 1 provides some descriptive statistics for the relation between the educational degree, participating in informal education and the amount of time spent on informal education for our two data sets. The education levels correspond to degrees after typically 9, 10, 12, and 13 years of schooling. For the time use data we report the average minutes for two days for the respective education group and the average participation rate for weekdays and weekend days pooled and for weekdays separately. There is a clear positive correlation between the amount of time spent on informal education or the participation rate and the educational degree. However, for the more formal activities INFOEDU2 this correlation is not as pronounced when comparing the intermediate with the higher schooling degrees (REAL to ABITUR). Not surprisingly, the average time spent on informal education according to the broader definition INFOEDU1 is higher when weekend days are included. But the general finding about the relation between schooling education and time spent on informal education is robust to the inclusion of weekend days. For weekdays we also report the average minutes of reported

\footnotetext{
${ }^{4}$ See again Table A.1 in the Appendix for details.

${ }^{5}$ Examples of related studies to our paper finding this relation are: Pfeiffer and Reize (2000) using the 1991 wave of the Q an C data for an analysis of incidences of jobrelated further education courses and seminars in Germany and Jenkins et al. (2002) investigating the determinants of lifelong learning in the UK, where lifelong learning is defined as acquiring a recognized qualification between the age of 33 and 42 . Also Sargant et al. (1997) identify in a study based on the surveys of NIACE on a broad notion of adult learning incidences in the UK initial education (schooling education) as one of the main determinants of learning later in life.
} 


\begin{tabular}{|c|c|c|c|c|}
\hline & HAUPT & REAL & FACHABI & ABITUR \\
\hline after normally & 9 & 10 & 12 & 13 \\
\hline & \multicolumn{4}{|c|}{ years of schooling } \\
\hline \multicolumn{5}{|c|}{ Time use data (1991/1992) } \\
\hline $\begin{array}{l}\text { Minutes in } \\
\text { two days } \\
\text { (participation) }\end{array}$ & & & & \\
\hline \multicolumn{5}{|c|}{ Weedays and weekends } \\
\hline Infoedu1 & \begin{tabular}{|l}
47.42 \\
$(0.6842)$
\end{tabular} & $\begin{array}{l}66.71 \\
(0.7418)\end{array}$ & \begin{tabular}{|l|}
71.46 \\
$(0.7514)$
\end{tabular} & $\begin{array}{l}75.65 \\
(0.8011)\end{array}$ \\
\hline Infoedu 2 & $\begin{array}{l}5.58 \\
(0.0573)\end{array}$ & $\begin{array}{l}13.33 \\
(0.1169)\end{array}$ & $\begin{array}{l}13.14 \\
(0.1514)\end{array}$ & $\begin{array}{l}15.80 \\
(0.1761)\end{array}$ \\
\hline$\%$ of total & 48.43 & 20.94 & 10.55 & 20.01 \\
\hline \multicolumn{5}{|l|}{ Only weekdays } \\
\hline Worktime & 994.23 & 973.42 & 1002.44 & 981.67 \\
\hline Infoedu1 & $\begin{array}{l}42.51 \\
(0.6631)\end{array}$ & $\begin{array}{l}59.79 \\
(0.725)\end{array}$ & $\begin{array}{l}61.20 \\
(0.7436)\end{array}$ & $\begin{array}{l}65.58 \\
(0.7511)\end{array}$ \\
\hline Infoedu2 & $\begin{array}{l}3.99 \\
(0.0486)\end{array}$ & $\begin{array}{l}13.19 \\
(0.1208)\end{array}$ & $\begin{array}{l}12.91 \\
(0.1538)\end{array}$ & $\begin{array}{l}14.03 \\
(0.1373)\end{array}$ \\
\hline \multicolumn{5}{|c|}{ Q and C data (1991/1992 and1998/1999) } \\
\hline Participation & & & & \\
\hline InfoeduQC1 & 0.8845 & 0.9480 & 0.9716 & 0.9820 \\
\hline InfoeduQC2 & 0.7077 & 0.8150 & 0.9092 & 0.9306 \\
\hline InfoeduQC3 & 0.4659 & 0.5848 & 0.6843 & 0.7578 \\
\hline$\%$ of total & 39.01 & 27.45 & 10.31 & 23.22 \\
\hline InfoeduQC4* & 0.3915 & 0.5150 & 0.6575 & 0.7319 \\
\hline$\%$ of total & 34.83 & 27.53 & 12.01 & 25.63 \\
\hline
\end{tabular}

Notes: For details on the different definitions of informal education see the table „Classification of Informal Education" and the text. We include only fulltime working men and exclude those without a schooling degree. We are left with 1760 observations in the time use data and 17940 oberservations in the pooled Q and C data (with 9431 in the 1998/1999 cross-section).

*This variable could only be constructed for the 1998/1999 cross-section.

Table 1: Schooling Education and Participation in and Time Spent on Informal Education 
worktime. Similar to Gronau and Hamermesh (2001), who use the same data, we find that there is no nonnegative relation between schooling and total hours worked in Germany as it is found in other countries. When turning to the survey data, the correlation between the schooling degree and the participation rates in informal education resembles a similar pattern. As the survey questions cover an incidence of informal education in the five years prior to the date of survey, the participation rates are higher than those in the two diary-days of the time use data. The differences in the participation rates for workers holding different schooling degrees are highest for participation in activities which we argue are exemplary for informal education: reading technical literature (InfoeduQC4).

\section{Explaining the Demand for Informal Education}

\subsection{Productive or High-Quality Leisure?}

So far the tabulations indicate a link between schooling education and time investments and participation in informal education. However, it is still unclear why higher educated people invest more leisure time in educational activities. There are two hypotheses. Firstly, the observed effect could simply reflect a pure wage effect in the sense that people with a higher educational degree face a higher wage rate and, due to work time constraints, prefer the leisure activity which adds to their productivity and has therefore the lowest opportunity cost. To be more precise, the substitution effect, which results typically in higher educated people working more hours than lower educated, leads to a substitution from normal leisure to educational leisure. The premises for this hypothesis are, however, that there are (institutional) constraints in substituting labor for leisure ${ }^{6}$ that educational leisure has a productivity component leading to lower opportunity costs compared to purely consumptive leisure, and that the human capital production function is assumed in a way that higher educated people have higher returns to informal education. The $\mathrm{Q}$ and $\mathrm{C}$ data allow to test the latter of these premises. Since the data provide information on participation in informal education in the five years before the date of the survey we are able to identify at least to some degree returns to informal education in a standard wage regression where we use the logarithm of the current monthly gross earning as the dependent variable. Our estimates will provide only a crude idea about the shape of the human capital production function as we make no attempts to control for selection issues which might bias the estimates. To identify increasing returns to informal education with the amount of schooling education we include a dummy for participation in informal education and interaction terms for the participation in informal education with the

\footnotetext{
${ }^{6}$ This is apparently the case in Germany as can be seen in Table 1.
} 
highest achieved schooling degree in addition to the standard explanatory variables of a wage regression. ${ }^{7}$ In fact, we find that the returns to informal education for people with higher secondary education (Fachabitur and Abitur) are ceteris paribus between 8 and 15 percent higher compared to workers investing in informal education with 9 years of schooling given the definitions InfoeduQC1 and InfoeduQC2. ${ }^{8}$ These findings give rise to the wage effect as one explanation for the finding that time investments in informal education are increasing in the educational degree.

A second explanation could be that educational leisure has a higher consumption value for higher educated people and the correlation between education and the time investments in informal education simply reflects a taste for high-quality leisure. We do not further speculate what this taste effect specifically is and how it comes about. ${ }^{9}$ In the next subsection we try to illustrate how the taste and productivity component work in a formal framework of the demand for informal education. In section 4 we try to discriminate between both hypotheses, which might explain the determinants for the demand for informal education, empirically. The empirical analysis as well as the theoretical framework in the next section attempt to analyze the individual demand for informal education after finishing school and given the occupational choice. This implies that we treat the decisions about the amount of education and the occupation as exogenous throughout this study.

\subsection{The Demand for Informal Education: A Theoretical Motivation}

With the characterization of informal education as being both, a job related activity and a leisure activity, the household production model is particularly suited for the analysis of the determinants of time spent on informal education compared to time spent on market or other non-market activities. Although there might be an interaction with the spouse when allocating time between household production and market work, informal education is typically not a jointly consumed activity. Since the model is only meant to illustrate the demand for informal education, we restrict the theoretical motivation to a basic model to analyze the allocation of time between different market and non-market activities and use a simple static household production model formulated for an individual with given technologies. The general static framework goes back to the time allocation analysis in Becker (1965). The model presented here follows an application of the model by

\footnotetext{
${ }^{7}$ The results are presented in table A.2 in the Appendix.

${ }^{8}$ This holds also for the definition InfoeduQC3.

${ }^{9}$ For instance, the taste effect could be due to a different time preference of higher educated people resulting in a lower discount rate typically associated with a higher education level, see Card (1999).
} 
Biddle and Hamermesh (1990), who modify the general model to analyze the demand for the non-market activity sleep.

As has been discussed in the preceding sections, activities of informal education are characterized as educational activities that are human capital enhancing. We assume in the following, that we can express these human capital enhancing effects directly in a productivity component or, to be more precise, the increase in human capital will directly map into a wage effect. The positive coefficient for the dummy indicating participation in informal education in Table A.2 supports this assumption. Accordingly, in the following model, individuals do not only derive direct utility from these leisure activities (a basic property inherent in all leisure activities) but moreover gain indirect utility because this productive leisure contributes to their market productivity and hence to their ability to consume utility increasing market goods.

In addition our model also accounts for the fact that higher educated individuals might derive higher utility from spending time on activities of informal education besides receiving higher returns to informal education. To this end, the basic model is augmented by a variable denoting the educational level of the individual, $\eta$. The presumption that higher educated people might have a higher consumption value of informal education is expressed in indexing the direct utility from informal education by $\eta$. This leads to an utility function defined over time spent on informal education, $T_{I}$, indexed by $\eta$ and the Hicksean composite commodity $Z$ which is increasing and concave in both arguments,

$$
U=U\left(Z, \eta T_{I}\right), \quad U_{j}>0, \quad U_{j j}<0, \quad \eta>0,
$$

where the individual subscript $i$ is dropped throughout the theoretical part for the ease of notation. $U_{j}$ and $U_{j j}$ denote the first and second derivative with respect to the $j^{\text {th }}$ argument of the utility function, respectively. We do not specify the sign of the cross-derivatives but mention the effect of additional assumptions on the cross-derivatives where appropriate. The fact that time investments in informal education are human capital enhancing, and therefore in a way productive, is modelled by adding $T_{I}$ indexed by a second wage parameter $\left(W_{2}\right)$ in addition to a basic wage parameter $\left(W_{1}\right)$ to the equation for the market wage $\left(W_{m}\right)$. The fact that higher educated workers get higher returns from informal education is accounted for by indexing $T_{I}$ in addition by the level of education $\eta$ to get

$$
W_{m}=W_{1}+W_{2} T_{I} \eta, \quad W_{1}, W_{2} \geq 0 .
$$

The time endowment is given by

$$
T^{*}=T_{Z}+T_{I}+T_{W} \quad \text { with } \quad T_{Z}, T_{I}, T_{W} \geq 0,
$$


where $T_{Z}$ is time spent producing commodity $Z$, and $T_{W}$ is work-time. The household production technology to produce the composite good $Z$ with the inputs time, $T_{Z}$, and basic goods which have to be bought at the market, $X$, is assumed to have fixed-coefficients.

$$
\begin{aligned}
T_{Z} & =b Z, \\
X & =a Z,
\end{aligned}
$$

where $X$ are the more basic goods which give no direct utility. The individuals goods constraint is the standard

$$
P X=W_{m} T_{W}+V,
$$

where $V$ is non-labor income. The combination of these constrains yields

$$
\left(W_{1}+W_{2} T_{I} \eta\right)\left(T^{*}-T_{I}-T_{Z}\right)+V=a P Z .
$$

Maximizing equation (1) subject to (7) yields the first order condition

$$
\frac{U_{1}}{U_{2}}=\frac{\left(a P+b W_{m}\right) \eta}{W_{1}+W_{2}\left(T_{I}-T_{W}\right) \eta} \quad \text { with } \quad Z, T_{I}>0 \quad \text { and } \quad T_{Z}, T_{W} \geq 0
$$

which states that the ratio of the marginal utilities of consumption and informal educational leisure must equal the ratio of their prices. The price of a unit of $Z$ reflects the cost of goods required to produce it and the shadow price of time needed for production. A higher preference for informal education, i.e. a higher $\eta$, is thereby reflected in a relatively higher price for $Z$. The price of a unit of informal education is the wage rate minus any effect on the wage rate from an increasing productivity due to investments in informal education, where the latter is higher for higher educated individuals.

\section{Comparative Statics ${ }^{10}$}

The effect on informal education of a change in other household income is given by

$$
\begin{aligned}
\frac{\partial T_{I}}{\partial V}= & \frac{1}{q^{2}}\left[\frac{q}{a P} U_{11}\left(W_{1}+W_{2}\left(T_{I}-T_{W}\right) \eta\right)\right. \\
& -U_{12} q \eta \\
& \left.+U_{1} b W_{2} \eta\right] \cdot \frac{1}{D^{2}}
\end{aligned}
$$

\footnotetext{
${ }^{10}$ Details about the derivation of the equations are available from the author upon request.
} 
where $q$ is the price of $Z, a P+b W_{m} . D^{2}$ denotes the second derivative $\frac{\partial^{2}}{\partial T_{I}^{2}} U\left(Z, \nu T_{I}\left(V, W_{1}, W_{2}\right)\right)$ and is negative by assumption. The first term on the right hand side has a positive influence on the effect of income on informal education. The second term reflects a positive effect only if informal education is a complement for all other goods. In this case, the positive influence of this term would be stronger, the higher the educational level $\eta$ of the individual. The third term in Equation (9) reflects a negative effect on informal education. This negative effect increases with the productivity effect of educational leisure and the education level. The negative sign results directly from the modelling of the technology for $Z$. Because $T_{Z}$ has to rise to increase utility with the purchased market goods and $T_{I}$ has a tendency to increase from the first term, the price of informal education falls in Equation (8) when $T_{W}$ decreases. The third term can therefore be seen as a second-order substitution effect. ${ }^{11}$

$$
\frac{\partial T_{I}}{\partial W_{1}}=\frac{1}{q a P}\left(a P U_{1}+q \eta b U_{2}\right) \cdot \frac{1}{D^{2}}+\frac{q}{a P} \cdot T_{W} \frac{\partial T_{I}}{\partial V}
$$

Equation (10) is the Slutzky equation describing the demand for informal education. While the first part reflects a negative impact on the demand for informal education, the total effect is ambiguous, because it is unclear what turns out for the income effect.

$$
\frac{\partial T_{I}}{\partial W_{2}}=\eta T_{I} \frac{\partial T_{I}}{\partial W_{1}}-\frac{1}{a P} U_{1} \eta T_{W} \cdot \frac{1}{D^{2}}
$$

The wage parameter $W_{2}$ which describes the investment component of productive leisure impacts less negatively or more positively on the demand for productive leisure. The total effect of changes in income or wage is an empirical question.

\section{Estimating the Demand for Informal Education}

\subsection{Empirical Strategy}

The influence of substitution effects and education is identified in the following equation with $i$ denoting the individual index

$$
T_{I i}=\beta_{0}+\beta_{1} X_{i}+\beta_{2} E D U_{i}+\beta_{3} W_{i}+\beta_{4} V_{i}+\beta_{5} O C C_{i}+\varepsilon_{i},
$$

where $E D U_{i}$, which is identical to our $\eta$ in the theoretical model, will be in fact a set of dummy variables reporting the highest educational degree. $X_{i}$ denotes other controls included in the estimation, $W_{i}$ identifies the market wage and $V_{i}$ the non-labor income. By including occupational

\footnotetext{
${ }^{11}$ The reasoning here is close to Biddle and Hamermesh (1990).
} 
dummies $O C C_{i}$ we control for heterogeneity in (informal) training demands for different occupations.

The inclusion of the market wage on the right hand side comes not without problems. Firstly, in the theoretical model we assumed the market wage $W_{m}$ as $W_{1}+W_{2} T_{I} \eta$. Accordingly, $W_{m}$ might be endogenous through the productivity component of informal education $W_{2}$. In fact there are clues that this is the case. ${ }^{12}$ Secondly, the economic variables and the wage rate in particular are measured with considerable measurement error in the time use data implicating in the case of a pure random measurement error downward biased estimates of the wage effect. To check the robustness of the results in the light of the aforementioned problems we compare the results with estimates including a predicted wage $\hat{W}_{1}$ as a right hand side variable. Thereby we predict the logarithm of the wage rate with the observable characteristics in the time use data with the parameters of a wage regression estimated with a comparable sub-sample of full-time working married men with the 1992 I-Wave of the GSOEP. ${ }^{13}$ The predicted wage is identified in the subsequent time use equation by the industry dummies. ${ }^{14}$

To compare the results with regressions using the $\mathrm{Q}$ and $\mathrm{C}$ data, where we have only information on participation in informal education, we will also use the time use data to estimate a model for the determinants of spending any time on activities of informal education at least at one of the diary days. The reference model for the participation equation is a simple Logit framework with $T_{I i}$ as the latent variable and the cumulative distribution of $\varepsilon_{i}$ assumed to be logistic. The alternatives are either to engage in informal education (INFOEDU $=1$, when $T_{I i}>0$ ) or not (INFOEDU =0), when $T_{I i}=0$.

In this study we are concerned about the determinants of regular participation in informal education. In this respect the two data sets at hand provide information in two extremes. On the one hand the survey data just report whether the respondent has participated in the respective activity at least once in the last five years prior to the date of the survey, in this way irregularly participation of respondents in informal education might bias our results. On the other hand the days covered in the two day time use journals might not be representative for an otherwise regular learner. To investigate

\footnotetext{
${ }^{12}$ We test whether estimates for the two structural equations with informal education as the dependent variable and the market wage as the dependent variable, where the wage or the time spent on informal education are included as explanatory variables respectively, are consistently estimated by least squares using a version of the Durbin-Wu-Hausmann test suggested in Davidson and MacKinnon (1993). In fact we find only for the equation with the minutes spent on informal education as the dependent variable weakly significant evidence that OLS estimates are not consistent and the market wage needs to be in fact instrumentized.

${ }^{13}$ See Appendix $\mathrm{C}$ for details.

${ }^{14}$ Training demands are supposed to differ on an occupational level rather than on an industry level. In fact, when including occupation and industry dummies in an estimation of Equation (12) only the coefficients for the occupation dummies turn out significant.
} 
the determinants of the amount of time spent on activities of informal education, we pool the minutes spent on informal education for two diary days. This makes it more likely to cover activities which take place on a non-daily basis.

The fact that we have individuals in the data set reporting no time at activities of informal education during their diary days creates a problem of censored regression. We employ Powell's censored least absolute deviations estimator (CLAD) (Powell (1984)) as the most appropriate estimator for the current purpose. This estimator is robust to heteroscedasticity, consistent and asymptotically normal for a wide class of error distributions. ${ }^{15}$

As the iterative procedure to estimate CLAD requires a sufficient amount of uncensored observations, we estimate the models only for the broadest definition of informal education in the time use data, INFOEDU1, as the dependent variable. While the estimates for $\beta_{2}$ and $\beta_{3}$ in Equation (12) will provide some first hints on the relative importance of taste and wage effects, we will improve on these estimates in two respects. Firstly, to identify a clear taste effect which is not polluted by any considerations about enhancing labor market productivity we will estimate an adapted version of Equation (12) for a sample of people for whom labor market considerations are no longer part of the individual choice set for institutional reasons. Secondly, even if the estimates for $\beta_{3}$ reveal a substitution effect in which ever direction there is need for further investigation. The wage effect might just be an artefact of the heterogeneity of the sample population as we only exploit cross-sectional variation. Moreover, it is still unclear which time budgets are adjusted when allocating more or less time to learning activities. Fortunately, the specific structure of the time use data will allow to provide more detailed information on these issues.

\subsection{Sample Selection}

Since the time use data were collected only shortly after the German reunification and the occupation and firm structure was fundamentally different in the German Democratic Republic which might also influence the individual attitude towards human capital investments, we follow Gronau and Hamermesh (2001) and restrict the sample to West German inhabitants only.

We use only information on full-time working men for two reasons. Firstly, we are interested in the determinants of the life-long learning component of a working individual's daily time use rather than the decision of labor supply. More precisely, we want to know what distinguishes a worker

\footnotetext{
${ }^{15}$ In our case, the distribution of the censored dependent variable (INFOEDU1) is extremely skewed which makes a normal distribution of the errors unlikely. A extremely skewed dependent variable has to be estimated with explanatory variables distributed in a very particular way to end up with normally distributed errors.
} 
participating in educational leisure from a worker who consumes other forms of leisure. Secondly, restricting the sample to full-time workers helps to reduce the error in the wage rate which we obtain by dividing the individuals monthly income as reported in the survey accompanying the time use data by the information on the normally worked weakly working hours. Because labor supply of women in Germany is much behind that of men, we end up with few observations for full-time working women. Because womens' time use might be influenced by other fundamentally different factors than that of men (child care, chores) we abstain from pooling full-time working men and women and retain only full-time working men for the purpose of our analysis. For the same reason we restrict the sample to married or cohabitating men. ${ }^{16}$

We include only individuals for whom diaries for two 'normal' days where available. ${ }^{17}$ Weekdays and weekend days will be pooled for the purpose of our analysis.

Because the main purpose for the use of $\mathrm{Q}$ and $\mathrm{C}$ data is to show the robustness of the results from the time use data, the selection in the $\mathrm{Q}$ and $\mathrm{C}$ data is done accordingly.

\subsection{Basic Results}

The first two columns in Table 2 report the basic results for the participation decision for our two definitions of informal education when occupational dummies are included. While INFOEDU2 is rather restricted to courses and some formal educational elements, INFOEDU1 includes a much broader notion of educational activities. When interpreting the results, one has to keep in mind that it is much more likely to observe routine activities such as reading than participation in courses among the activities reported in the two days of diary keeping.

Inspecting first the model without economic variables on the right hand side (column 1) we find a considerable significant positive effect for the highest educational degree (Abitur) compared to the lowest degree, where having an Abitur degree increases the incidence of informal education for both definitions by about $8 \%$, holding other influences constant. For the broad definition of informal education (INFOEDU1), intermediate educational levels show a positive but insignificant effect on the participating in informal education. However, it is still unclear whether this positive effect

\footnotetext{
${ }^{16}$ We loose only $15 \%$ of the observations by this restriction.

${ }^{17}$ One question in the questionnaire accompanying the time use data set asks whether the diary days are normal work-days or holidays, days of sickness, or family celebrations. About $25 \%$ of all reported days were considered as non-normal days according to this question. We restrict our analysis to people reporting normal days as we are interested in the time use on "routine" days. However, it is unclear, how a non-normal day affects the time devoted to activities of informal education. As a robustness check we do all our estimates also with all journal days (including non-normal days).
} 


\begin{tabular}{|c|c|c|c|c|c|c|}
\hline & \multicolumn{3}{|c|}{ INFOEDU1 (yes=1) } & \multicolumn{3}{|c|}{ INFOEDU2 (yes=1) } \\
\hline & (1) & (2) & (3) & (1) & (2) & (3) \\
\hline $\mathrm{AGE}$ & $\begin{array}{l}0.026 * * \\
(0.011)\end{array}$ & $\begin{array}{l}0.027 * * \\
(0.011)\end{array}$ & $\begin{array}{l}0.024 * * \\
(0.011)\end{array}$ & $\begin{array}{l}-0.002 \\
(0.006)\end{array}$ & $\begin{array}{l}-0.0004 \\
(0.006)\end{array}$ & $\begin{array}{l}-0.001 \\
(0.006)\end{array}$ \\
\hline $\operatorname{AGE}^{2}\left(\mathrm{x} 10^{-2}\right)$ & $\begin{array}{l}-0.025^{* *} \\
(0.012)\end{array}$ & $\begin{array}{l}-0.026 * * \\
(0.012)\end{array}$ & $\begin{array}{l}-0.022 * \\
(0.012)\end{array}$ & $\begin{array}{l}0.003 \\
(0.007)\end{array}$ & $\begin{array}{l}0.001 \\
(0.007)\end{array}$ & $\begin{array}{l}0.002 \\
(0.006)\end{array}$ \\
\hline REAL $^{\circ}$ & $\begin{array}{l}0.041 \\
(0.029)\end{array}$ & $\begin{array}{l}0.038 \\
(0.029)\end{array}$ & $\begin{array}{l}0.040 \\
(0.028)\end{array}$ & $\begin{array}{l}0.048 * \\
(0.028)\end{array}$ & $\begin{array}{l}0.052 * \\
(0.028)\end{array}$ & $\begin{array}{l}0.055^{* *} \\
(0.025)\end{array}$ \\
\hline $\mathrm{FACHABI}^{\circ}$ & $\begin{array}{l}0.029 \\
(0.039)\end{array}$ & $\begin{array}{l}0.025 \\
(0.040)\end{array}$ & $\begin{array}{l}0.038 \\
(0.038)\end{array}$ & $\begin{array}{l}0.087 * * \\
(0.044)\end{array}$ & $\begin{array}{l}0.100 * * \\
(0.047)\end{array}$ & $\begin{array}{l}0.100 * * \\
(0.041)\end{array}$ \\
\hline ABITUR $^{\circ}$ & $\begin{array}{l}0.080 * * \\
(0.033)\end{array}$ & $\begin{array}{l}0.076 * * \\
(0.035)\end{array}$ & $\begin{array}{l}0.090 * * * \\
(0.032)\end{array}$ & $\begin{array}{l}0.098 * * * \\
(0.035)\end{array}$ & $\begin{array}{l}0.115 * * * \\
(0.040)\end{array}$ & $\begin{array}{l}0.118 \text { *** } \\
(0.034)\end{array}$ \\
\hline SHIFT $^{\circ}$ & $\begin{array}{l}-0.042 \\
(0.034)\end{array}$ & $\begin{array}{l}-0.005 \\
(0.034)\end{array}$ & $\begin{array}{l}-0.009 \\
(0.008)\end{array}$ & $\begin{array}{l}-0.012 \\
(0.025)\end{array}$ & $\begin{array}{l}-0.011 \\
(0.025)\end{array}$ & $\begin{array}{l}-0.017 \\
(0.022)\end{array}$ \\
\hline FLEXI $^{\circ}$ & $\begin{array}{l}0.013 \\
(0.026)\end{array}$ & $\begin{array}{l}0.016 \\
(0.026)\end{array}$ & $\begin{array}{l}0.008 \\
(0.026)\end{array}$ & $\begin{array}{l}-0.001 \\
(0.017)\end{array}$ & $\begin{array}{l}-0.0003 \\
(0.016)\end{array}$ & $\begin{array}{l}-0.002 \\
(0.014)\end{array}$ \\
\hline $\mathrm{URBAN}^{\circ}$ & $\begin{array}{l}-0.119 * * * \\
(0.035)\end{array}$ & $\begin{array}{l}-0.124 * * * \\
(0.036)\end{array}$ & $\begin{array}{l}-0.117 * * * \\
(0.034)\end{array}$ & $\begin{array}{l}-0.041 * * \\
(0.020)\end{array}$ & $\begin{array}{l}-0.040 * * \\
(0.020)\end{array}$ & $\begin{array}{l}-0.038 * * \\
(0.018)\end{array}$ \\
\hline SEMIURBAN $^{\circ}$ & $\begin{array}{l}-0.145^{* * *} \\
(0.043)\end{array}$ & $\begin{array}{l}-0.149 * * * \\
(0.044)\end{array}$ & $\begin{array}{l}-0.138 * * * \\
(0.042)\end{array}$ & $\begin{array}{l}-0.040 * * \\
(0.017)\end{array}$ & $\begin{array}{l}-0.040 * * \\
(0.018)\end{array}$ & $\begin{array}{l}-0.039 * * \\
(0.016)\end{array}$ \\
\hline LOGWAGE & & $\begin{array}{l}0.067 \\
(0.045)\end{array}$ & $\begin{array}{l}0.094 * * \\
(0.044)\end{array}$ & & $\begin{array}{l}-0.008 \\
(0.027)\end{array}$ & $\begin{array}{l}0.003 \\
(0.024)\end{array}$ \\
\hline LOGINC & & $\begin{array}{l}-0.053 \\
(0.041)\end{array}$ & $\begin{array}{l}-0.064 \\
(0.041)\end{array}$ & & $\begin{array}{l}-0.034 \\
(0.025)\end{array}$ & $\begin{array}{l}-0.033 \\
(0.023)\end{array}$ \\
\hline OCC-Dummies & Yes & Yes & No & Yes & Yes & No \\
\hline Likelihood & -985.52 & -984.31 & -1005.28 & -522.99 & -521.23 & -547.03 \\
\hline Pseudo- $\mathrm{R}^{2}$ & 0.045 & 0.046 & 0.0261 & 0.074 & 0.077 & 0.0653 \\
\hline $\mathrm{N}$ & 1758 & 1758 & 1760 & 1582 & 1582 & 1760 \\
\hline
\end{tabular}

Notes: Marginal effects for fulltime working men in West Germany reporting "normal" days. We drop those without any schooling education. For the definition of the dependent variables see text and Table 1 . Robust standard errors are reported in parentheses. Reference groups are 9 years of schooling (Hauptschule), normal work schedule, living in rural area. Additional controls included in the regressions are number of children and controls for the job status.

Statistical significance at the $1 \%(5 \%, 10 \%)$ level denoted $* * *(* * *)$.

${ }^{\circ}$ For this variables we report the marginal effect for a discrete change of the dummy variable from 0 to 1.

Table 2: Determinants of Participating in Informal Education (Time Use Data, Logit Models, Marginal Effects) 
for education reflects a wage or a taste effect. In estimates including the logarithm of the wage and household income (column 2 of Table 2), we find an insignificant positive wage effect along with the still significantly positive effect for having the top schooling degree and a negative but insignificant income effect for the broad definition of informal education. In the specification where we do not include controls for occupation the wage effect turns out significantly positive. Apparently, higher education as measured by the highest achieved schooling degree is associated with higher participation rates in informal education independent from wage effects and reflects thereby an effect which we interpret as a taste effect. The positive wage effect along with no significant income effect indicates a positive substitution effect which can only be explained by a strong productivity component of informal education along the lines of our theoretical set up.

The marginal effect for the predicted wage rate ${ }^{18}$ in a model of type 2 as in Table 2 with INFOEDU1 as the dependent variable is $0.242(0.165)$. With INFOEDU2 as the dependent variable this effect is estimated to be 0.191 (0.121). Robust standard errors are in parentheses. This supports the findings from the estimates with the wage measure from the time use data. The fact that the estimated coefficients for the predicted $\hat{W}_{1}$ are so much higher than with the wage measure with the time use data, indicates a considerable measurement error in the wage measure of the time use data. This is even more true, as the comparative statics from the theoretical model predict a smaller effect for the wage component $W_{1}$ compared to the total market wage including the educational productivity component $W_{2}$ in the case of an (according to the theoretical set-up without a strong positive income effect unlikely) positive substitution effect. The standard errors for the education dummies increase when including the predicted wage measure. We interpret this as a problem of multicollinearity, since the education dummies are important explanatory variables in the prediction of the wage rate. This interpretation is confirmed when including all variables of the wage equation instead of the predicted wage in the time use equation. In fact, we find in estimates not reported here significantly positive education dummies along with significant variables from the wage equation. Overall, taking the problem of identifying substitution effects with cross-sectional data aside, which will be discussed below, the finding of a positive substitution effect at least for participating in informal education seems to be fairly robust.

Moreover, we find a significantly negative effect of living in more densely populated areas on the participation in informal education. ${ }^{19}$ For age we

\footnotetext{
${ }^{18}$ See Appendix $\mathrm{C}$ for details on the prediction of the wage rate.

${ }^{19}$ One would expect people living in cities to have lower costs to participate in educational activities which take place away from home, simply because the required facilities are more near by in cities than in rural areas. Inspection of Table 2 shows, that people living in urban regions tend also to participate significantly less in course based informal education (INFOEDU2), however this effect is not as pronounced as for INFOEDU1. A
} 
found a hump shaped positive effect for INFOEDU1 and, a bit surprisingly, no effect for the dummies indicating the work time schedule. ${ }^{20}$

As discussed above, a potential problem with the time use data is, that it only covers activities during the two diary days. The survey covers participation in informal education in the five years prior to the date of the survey relying on the memory of the respondents. We find a clear positive effect for the highest educational degree on the incidence of informal education. ${ }^{21}$ The probability to participate in informal education for holders of the highest schooling degree, other things being equal, ranges between $2.3 \%$ for the broadest definition of the dependent variable to $17.2 \%$ when defining reading technical literature as the dependent variable. Clear positive effects are also found for intermediate educational levels. When including monthly gross earnings, the only economic variable in the $\mathrm{Q}$ and $\mathrm{C}$ data, we find a positive significant effect ranging from $2.8 \%$ for the broadest definition of informal education to $20.8 \%$ for reading technical literature as the dependent variable. The positive effect for education is preserved at a similar size when earnings are included on the right hand side. This finding confirms the results from the time use data set, namely that a strong positive substitution effect along with a taste effect determines the participation in informal education.

The first two columns of Table 3 provide the basic results for the estimation of a CLAD model for the minutes spent on informal education (INFOEDU1) during two days as the dependent variable. Because convergence is not achieved with a full set of occupational controls we include an indicator variable for working in a skill demanding occupation. The coefficients have to be interpreted as partial effects on the time spent on informal education conditional on doing any informal education at all. At least for the highest educational degree (Abitur) compared to the lowest educational degree we found a significant positive effect increasing the amount spent on informal education by 15.2 minutes other things equal. This effect is only slightly reduced to 14 minutes when including economic variables. Column 2 shows that an increase in the wage by one percent increases the time spent

possible explanation for the observed urban effect is that big cities provide much more leisure opportunities than a village in the countryside and consequently the inhabitants of cities are less inclined to participate in activities of informal education.

${ }^{20}$ In regression not reported here we also include a dummy variable indicating whether the spouse invests time in informal education. This dummy turns out consistently significantly positive indicating a joint component in the consumption of informal education. While we still find significantly positive effects for the highest obtained schooling degree the positive substitution effects vanishes even in the specification without occupational controls. This indicates that the coordination of time use between spouses is an important issue (cf. Hamermesh (2002)). Because we want to estimate a model which is as comparable as possible with the survey data we refrain from including this dummy variable in all estimates.

${ }^{21}$ Detailed results can be found in Table A.3 in the Appendix. 


\begin{tabular}{|c|c|c|c|}
\hline & \multicolumn{3}{|c|}{ INFOEDU1 in Minutes in two days } \\
\hline & (1) & (2) & (3) \\
\hline AGE & $\begin{array}{l}1.151 \\
(1.985)\end{array}$ & $\begin{array}{l}0.477 \\
(1.865)\end{array}$ & $\begin{array}{l}0.764 \\
(1.822)\end{array}$ \\
\hline $\operatorname{AGE}^{2}\left(\times 10^{-2}\right)$ & $\begin{array}{l}-0.627 \\
(2.201)\end{array}$ & $\begin{array}{l}0.148 \\
(2.055)\end{array}$ & $\begin{array}{l}-0.207 \\
(2.001)\end{array}$ \\
\hline REAL & $\begin{array}{l}8.746^{*} \\
(4.574)\end{array}$ & $\begin{array}{l}7.281 \\
(4.660)\end{array}$ & $\begin{array}{l}7.270 \\
(5.142)\end{array}$ \\
\hline FACHABI & $\begin{array}{l}9.003 \\
(7.744)\end{array}$ & $\begin{array}{l}7.462 \\
(6.171)\end{array}$ & $\begin{array}{l}6.305 \\
(7.292)\end{array}$ \\
\hline ABITUR & $\begin{array}{l}15.222 * * * \\
(5.271)\end{array}$ & $\begin{array}{l}14.000 * * * \\
(5.557)\end{array}$ & $\begin{array}{l}13.483^{* *} \\
(5.862)\end{array}$ \\
\hline URBAN & $\begin{array}{l}-13.213 * * * \\
(4.312)\end{array}$ & $\begin{array}{l}-16.425 * * * \\
(4.982)\end{array}$ & $\begin{array}{l}-14.603 * * * \\
(5.197)\end{array}$ \\
\hline SEMIURBAN & $\begin{array}{l}-17.767 * * * \\
(4.623)\end{array}$ & $\begin{array}{l}-19.872 * * * \\
(4.856)\end{array}$ & $\begin{array}{l}-17.534 * * * \\
(5.576)\end{array}$ \\
\hline LOGWAGE & - & $\begin{array}{l}15.365^{* *} \\
(7.703)\end{array}$ & $\begin{array}{l}17.581 * * \\
(7.736)\end{array}$ \\
\hline LOGINC & - & $\begin{array}{l}-9.569 \\
(5.570)\end{array}$ & $\begin{array}{l}-9.273 \\
(5.963)\end{array}$ \\
\hline HIGHSKILL & $\begin{array}{l}5.466 \\
(4.045)\end{array}$ & $\begin{array}{l}5.339 \\
(4.235)\end{array}$ & - \\
\hline Constant & $\begin{array}{l}9.172 \\
(43.898)\end{array}$ & $\begin{array}{l}59.942 \\
(51.489)\end{array}$ & $\begin{array}{l}45.677 \\
(52.735)\end{array}$ \\
\hline Pseudo- $\mathrm{R}^{2}$ & 0.028 & 0.030 & 0.030 \\
\hline $\mathrm{N}$ & 1760 & 1760 & 1760 \\
\hline
\end{tabular}

Notes: Censored LAD for fulltime working men in West Germany reporting "normal" days. We drop those without any schooling education. For the definition of the dependent variable see text and Table 1. Bootstrapped standard errors are reported in parentheses and are robust to heterogeneity. Reference groups are 9 years of schooling (Hauptschule), normal work schedule, living in rural area. Additional controls included in the regressions are number of children, dummy for children in pre-school age, and controls for the job status. HIGHSKILL indicates working in a skill demanding occupation and is included, because convergence is not achieved with a full set of occupation dummies.

Statistical significance at the $1 \%(5 \%, 10 \%)$ level denoted $* * *(* * *)$.

Table 3: Determinants of Time Investments in Informal Education (Censored LAD Estimates) 
on informal education by 15.4 minutes. ${ }^{22}$ Not surprisingly, this effect is even stronger when not controlling for skill demanding occupations as in column 3. The absolute numbers seem to be small given the available amount of time in two days. But one has to keep in mind that informal education might still make up for a reasonable amount of remaining time after deducing work, sleep, personal care etc. When instrumentizing the wage we get a coefficient of 24.105 (s.e. 23.381) which is positive but insignificant. All in all, the results confirm the findings of the participation model.

\subsection{Identifying the Taste Effect}

The empirical results in the foregoing sub-section suggest that the influence from the highest obtained educational degree on the demand for informal education seems indeed to be mostly a taste effect. This is suggested by the fact that the impact from the dummies for the highest obtained schooling degree on the participation in and absolute amount of time spent on informal education is only slightly decreased by the inclusion of economic variables. However, the interpretation of the results in this way relies on the assumption, that our economic variables capture all potential wage effects. To get clear evidence for a taste effect it would be desirable to estimate an adapted version of Equation (12) for a sample of individuals for whom a potential correlation between the educational degree and time spent on informal education resembles nothing but a taste effect.

With a few exceptions there is a mandatory retirement age in Germany. This implies that the institutional setting guarantees that considerations involving the individual market value play no role for retirees when deciding upon the time spent on informal education. While the $\mathrm{Q}$ and $\mathrm{C}$ data covers only individuals in the workforce we are able to construct a sub-sample of married male retirees in the time use data allowing a comparison with the estimation results for our sample of married male workers in the section above.

Table 4 displays the estimation results for the participation model for our sample of economically inactive men. The reduced number of explanatory variables is supposed to explain the time use of retirees. However, there are no significant coefficients for spending time on activities of the broad definition of informal education (INFOEDU1) and the model has virtually no explanatory power. But we find a significant positive effect for having obtained a degree after 13 years of schooling (Abitur) on spending any time on INFOEDU2. Having Abitur increases the the probability to spent time at the more course based informal education activities (INFOEDU2) about considerable $8 \%$ which is slightly lower than the comparable effect for working men after controlling for the economic variables. As for the participation

\footnotetext{
${ }^{22}$ Regressions of an in this case inappropriate Tobit model yield qualitatively similar results.
} 
model we found for CLAD estimates not reported here no significant effects for the amount of time spent on informal education, which could only be estimated for INFOEDU1 for reasons explained above. Taking the results in this sub-section and the results in the foregoing sub-section we conclude that the correlation between the educational level and the participation in informal education mainly resembles a taste effect.

\begin{tabular}{|c|c|c|c|c|}
\hline & \multicolumn{2}{|c|}{ INFOEDU1 (yes=1) } & \multicolumn{2}{|c|}{ INFOEDU2 (yes=1) } \\
\hline & $d y / d x$ & s.e. & $\mathrm{dy} / \mathrm{dx}$ & s.e. \\
\hline AGE & 0.006 & $(0.011)$ & 0.023 & $(0.019)$ \\
\hline $\operatorname{AGE}^{2}\left(\times 10^{-2}\right)$ & -0.005 & $(0.008)$ & -0.019 & $(0.015)$ \\
\hline $\mathrm{REAL}^{\circ}$ & -0.002 & $(0.036)$ & 0.023 & $(0.032)$ \\
\hline FACHABI $^{\circ}$ & 0.060 & $(0.040)$ & -0.028 & $(0.032)$ \\
\hline ABITUR $^{\circ}$ & 0.001 & $(0.036)$ & $0.077 * *$ & $(0.039)$ \\
\hline $\mathrm{URBAN}^{\circ}$ & 0.025 & $(0.045)$ & 0.038 & $(0.036)$ \\
\hline SEMIURBAN $^{\circ}$ & -0.004 & $(0.046)$ & 0.033 & $(0.053)$ \\
\hline Likelihood & \multicolumn{2}{|c|}{-178.40} & \multicolumn{2}{|c|}{-119.70} \\
\hline Pseudo- $\mathrm{R}^{2}$ & \multicolumn{2}{|c|}{0.009} & \multicolumn{2}{|c|}{0.048} \\
\hline $\mathrm{N}$ & \multicolumn{2}{|c|}{522} & \multicolumn{2}{|c|}{522} \\
\hline
\end{tabular}

Notes: Marginal effects for married male retirees in West Germany. We drop those without any schooling education. For the definition of the dependent variables see text and Table 1. Robust standard errors are reported in parentheses. Reference groups are 9 years of schooling (Hauptschule), living in rural area.

Statistical significance at the $1 \%(5 \%, 10 \%)$ level denoted $* * *(* *, *)$.

${ }^{\circ}$ For this variables we report the marginal effect for a discrete change of the dummy variable from 0 to 1 .

Table 4: Determinants of Participating in Informal Education for Retirees (Time Use Data, Logit Models, Marginal Effects)

\subsection{Further Evidence for the Substitution Effect}

So far we found evidence for a positive substitution effect for our different activities of informal education in both data sets used for this study. There are two reasons to investigate this finding in more detail. Firstly, we have only used cross-sectional variation to detect the wage effect. Due to the heterogeneity of the population, the substitution effect might be blurred. At the same time, the time use data provide diaries for two consecutive 
days and we are therefore able to observe intra-personal changes in the determinants of time use behavior. Secondly, we did not take the fact that different constraints for the supply of labor on weekdays and weekends are in effect into account. To be more precise, on weekends, when individuals are typically not allowed to substitute more working hours for leisure for institutional reasons, we expect a strong positive substitution effect for informal education, because during weekends informal education is the most productive time use for people who would without constraints prefer to supply more hours of work. During weekdays, substitution effects should be less positive or negative. The substitution effects for informal education for two days during weekends or two weekdays should not be much different. To exploit the intra-personal variation we adopt a similar approach as Gronau and Hamermesh (2001) and estimate the following double difference equation:

$$
\begin{aligned}
\Delta_{i}^{2}= & \frac{\partial\left(T_{I, i, t, \text { Day }}-T_{I, i, \bar{t}, \text { End }}\right)}{\partial W}-\frac{\partial\left(T_{I, i, t, j}-T_{I, i, \bar{t}, j}\right)}{\partial W} \\
& \text { with } j=\text { Day, End }, t=1,2 \text { and } \bar{t}=2,1,
\end{aligned}
$$

and $i$ indexing individual diaries and Day and End denoting diaries on weekdays and weekend days, respectively. $t$ and $\bar{t}$ denote the first or the second diary day for each individual. For the estimates we construct two samples in which we include only individuals with two diaries on consecutive days: One sample includes respondents with one diary on a weekday and one diary on a weekend day. With this sample (417 observations) we estimate the first part of Equation (13). Then we have a sample pooling individuals with both diaries on a weekend day or both diaries on a weekday, this pooled sample (1412 observations) is used to estimate the second part of Equation (13). From the reasoning above we expect the double difference $\Delta^{2}$ to be negative, which would confirm the positive substitution effect found above. Moreover we would have clear evidence that this substitution effect results from substituting informal education for other leisure time instead of substituting informal education for labor. Estimating the individual difference equations with the same right hand side variables as for models (2) in section 4.3 delivers for the double difference in Equation (13): $\Delta^{2}=-32.78$ [s.e. $14.00]-(-3.18$ [s.e. 5.52$])=-29.6$ [s.e. 15.05$].{ }^{23}$ In fact, the wage-informal education gradient is steeper for people with a weekday and a weekend day diary. This result provides evidence for a clear substitution effect which is not only an artefact of the cross-sectional structure of our data. Moreover, we know that this substitution effect is driven by a substitution from other leisure time to informal education rather than substitution from work time to informal education.

\footnotetext{
${ }^{23}$ The results with the predicted wage $\hat{W}_{1}$ are $\Delta^{2}=-86.19$ [s.e. 50.21] -19.39 [s.e. $22.59]=-105.58[$ s.e. 55.06$]$.
} 


\section{Conclusion}

This paper investigated the determinants of participation in and spending time on informal educational leisure activities. The availability of detailed time use data for Germany allowed to contribute to the scarce empirical literature on informal forms of training and education. We argued that the relation between the level of schooling education and the participation in and the amount of adult learning could reflect a wage or a taste effect. Interpreting our results along the lines of a theoretical motivation encompassing both hypotheses and treating the amount of schooling education as exogenously given, we found evidence for both, a wage and a taste effect where the taste effect seems to be more important.

With estimates based on a sample of people for which wage effects are supposed to be irrelevant for institutional reasons we found evidence that the utility function concerning the preferences for informal education seem to be different for different education levels. As Jenkins et al. (2002) we found evidence for a "love to learn" associated with the amount of schooling education.

Exploiting the particular structure of our data we found that the positive wage effect on the amount of time invested in informal education results from higher educated people substituting the leisure activity which is most "productive" for other leisure activities. This effect is even more important when the labor supply is constraint. The descriptive part suggests that the latter is the case in Germany.

A comparison with an analysis based on survey data shows the robustness of the results and proofs that the use of time use data is an appropriate way to investigate issues of training and education.

Overall, this analysis shows that highly educated people accumulate human capital through their specific leisure time use. The attitude towards learning is an important determinant of labor market success associated with the observable formal schooling degrees. This effect tends to further increase the skill-gap between higher and lower educated people.

Going beyond the framework of this paper which treated the choice of the individual level of schooling as exogenous, the amount of schooling education reflects probably exactly the "love to learn". Evidence on the success of early childhood programs (see Currie (2001) for an overview) as well as insights in the recent neurobiological literature suggest that the foundation for the future attitude towards learning will be laid in the very early childhood. Further work is necessary to find out more about the formation of preferences to target policies to increase participation in adult learning more efficiently.

A detailed analysis of the returns to informal education is awaiting the availability of longitudinal data with detailed information on wages and participation in informal education. 


\section{References}

Bartel, A. P., and N. Sicherman (1998): "Technological Change and the Skill Acquisition of Young Workers," Journal of Labor Economics, 16(4), 718-755.

Becker, G. S. (1965): "A Theory of the Allocation of Time," Economic Journal, 75, 493-517.

Biddle, J. E., And D. S. Hamermesh (1990): "Sleep and the Allocation of Time," Journal of Political Economy, 98, 922-943.

Bowles, S., H. Gintis, and M. Osborne (2001): "The Determinants of Earnings: A Behavioral Approach," Journal of Economic Literature, 39, $1137-1176$.

CARD, D. (1999): "The Causal Effect of Education on Earnings," in Handbook of Labour Economics Volume 3A, ed. by O. Ashenfelter, and D. Card. Elsevier, Amsterdam.

Currie, J. (2001): "Early Childhood Education Programs," Journal of Economic Perspectives, 15(2), 213-238.

Davidson, R., and J. G. MacKinnon (1993): Estimation and Inference in Econometrics. Oxford University Press, New York, Oxford.

Gould, E. D. (2002): "Rising Wage Inequality, Comparative Advantage, and the Growing Importance of General Skills in the United States," Journal of Labor Economics, 20(1), 105-147.

Gronau, R., and D. S. Hamermesh (2001): "The Demand for Variety: A Household Production Perspective," NBER Working Paper W8509.

Haisken-DeNew, J. P., And C. M. Schmidt (1997): "Interindustry and Interregion Differentials: Mechanics and Interpretation," Review of Economics and Statistics, 79(3), 516-521.

(1999): "Industry Wage Differentials Revisited: A Longitudinal Comparison of Germany and USA (1984-1996)," .

Hamermesh, D. S. (2002): "Timing, Togetherness and Time Windfalls," Journal of Population Economics, Forthcoming.

Jenkins, A., A. Vignoles, A. Wolf, and F. Galindo-Rueda (2002): "Teh Determinants and Effects of Lifelong Learning," Centre for the Economics of Education, LSE, Discussion Paper No. 19.

Johnston, D. J. (1998): "Lifelong Learning for All," OECD Observer, (214). 
Kooreman, P., And A. Kapteyn (1987): "A Disaggregated Analysis of the Allocation of Time Within the Household," Journal of Political Economy, 95, 223-249.

Krueger, A. B., and L. Summers (1988): "Efficiency Wages and the Inter-Industry Wage Structure," Econometrica, 56, 259-293.

Pfeiffer, F., And F. Reize (2000): "Formelle und Informelle Berufliche Weiterbildung und Verdienst Bei Arbeitnehmern und Selbständigen," ZEW Discussion Paper No. 00-01.

Powell, J. L. (1984): "Least Absolute Deviation Estimation for the Censored Regression Model," Journal of Econometrics, 25(3), 303-325.

Sargant, N., J. Field, H. Francis, T. Schuller, and A. Tuckett (1997): The Learning Divide: A Study of Participation in Adult Learning in the United Kingdom. National Institute of Adult Continuing Education (NIACE).

Wagner, G. G., R. V. Burkhauser, and F. Behringer (1993): "The English Language Public Use File of the German Socio-Economic Panel Study," The Journal of Human Resources, 28, 429-433. 
A Appendix Tables 


\begin{tabular}{|c|c|c|}
\hline \multicolumn{3}{|c|}{ Time Use Data (1991/1992) } \\
\hline Informal Education Definition & Variable Name in Data Set & Description of Variables \\
\hline \multirow[t]{3}{*}{ Infoedu2 } & 420 & $\begin{array}{l}\text { Educational activities after work- } \\
\text { time which serve your current } \\
\text { job (e.g. training courses after } \\
\text { work-time, reading technical } \\
\text { literature) }\end{array}$ \\
\hline & 430 & $\begin{array}{l}\text { Educational activities which } \\
\text { serve your household activities }\end{array}$ \\
\hline & 440 & $\begin{array}{l}\text { Qualification for personal } \\
\text { reasons (e.g. courses at further } \\
\text { education college) }\end{array}$ \\
\hline \multirow[t]{6}{*}{ Infoedu 1} & Infoedu2 & \\
\hline & 715 & Reading daily newspaper \\
\hline & 716 & Reading journals \\
\hline & 717 & $\begin{array}{l}\text { Reading without further } \\
\text { specification (e.g. hobby- } \\
\text { literature) }\end{array}$ \\
\hline & 718 & $\begin{array}{l}\text { Working with the personal } \\
\text { computer (excluding computer } \\
\text { games) }\end{array}$ \\
\hline & 231 & $\begin{array}{l}\text { Work-related events after work- } \\
\text { time (e.g. conferences, fairs) }\end{array}$ \\
\hline \multicolumn{3}{|c|}{ Q and C data (1991/1992 and 1998/1999) } \\
\hline InfoeduQC4* & V724 & Reading technical literature \\
\hline InfoeduQC3 & V273, V724, V725 & $\begin{array}{l}\text { Reading technical literature, } \\
\text { other job/occupation related } \\
\text { further education }\end{array}$ \\
\hline InfoeduQC2 & InfoeduQC3, 267, 268, 718, 719 & $\begin{array}{l}\text { fairs, congresses, job/occupation } \\
\text { related seminars }\end{array}$ \\
\hline InfoeduQC1 & InfoeduQC2, 258, 716 & $\begin{array}{l}\text { Job/occupation related further } \\
\text { education/training courses }\end{array}$ \\
\hline
\end{tabular}

Notes: The three digit code refers to the activity codes in the Scientific Use File of the German Time Use Data 1991/1992. For the Q and C data the numbers refer to the variables in the 1991/1992 and 1998/1999 cross-section.

*This variable could only be constructed for the 1998/1999 cross-section.

Table A.1: Classification of Activities of Informal Education 


\begin{tabular}{|c|c|c|}
\hline \multicolumn{3}{|c|}{$\begin{array}{c}\text { Dependent Variable: Logarithm of gross monthly earnings } \\
\text { (deflated in terms of } 1995 \text { earnings) }\end{array}$} \\
\hline & InfoeduQC1 & InfoeduQC2 \\
\hline Age & $\begin{array}{l}0.045^{* * *} \\
(0.002)\end{array}$ & $\begin{array}{l}0.045^{* * * *} \\
(0.002)\end{array}$ \\
\hline $\operatorname{Age}^{2} \times 10^{-2}$ & $\begin{array}{l}0.041^{* * *} \\
(0.002)\end{array}$ & $\begin{array}{l}0.040^{* * * *} \\
(0.002)\end{array}$ \\
\hline Married & $\begin{array}{l}0.116^{* * * *} \\
(0.008)\end{array}$ & $\begin{array}{l}0.108 * * * \\
(0.008)\end{array}$ \\
\hline $\begin{array}{l}\text { Real (10 years } \\
\text { schooling) }\end{array}$ & $\begin{array}{l}0.060^{* *} \\
(0.026)\end{array}$ & $\begin{array}{l}0.067 * * * \\
(0.015)\end{array}$ \\
\hline $\begin{array}{l}\text { Fachabi }(12 \text { years } \\
\text { schooling) }\end{array}$ & $\begin{array}{l}0.117 * * \\
(0.055)\end{array}$ & $\begin{array}{l}0.153 * * * \\
(0.029)\end{array}$ \\
\hline $\begin{array}{l}\text { Abitur ( } 13 \text { years } \\
\text { schooling) }\end{array}$ & $\begin{array}{l}0.150 * * * \\
(0.050)\end{array}$ & $\begin{array}{l}0.193 * * * \\
(0.025)\end{array}$ \\
\hline InfoeduQC1 & $\begin{array}{l}0.075^{* * *} \\
(0.013)\end{array}$ & \\
\hline InfoeduQC2 & & $\begin{array}{l}0.057 * * * \\
(0.010)\end{array}$ \\
\hline InfoeduQC1*Real & $\begin{array}{c}0.039 \\
(0.027) \\
\end{array}$ & \\
\hline InfoeduQC1*Fachabi & $\begin{array}{l}0.115^{* *} \\
(0.055)\end{array}$ & \\
\hline InfoeduQC1*Abitur & $\begin{array}{l}0.155^{* * * *} \\
(0.050)\end{array}$ & \\
\hline InfoeduQC $2 *$ Real & & $\begin{array}{c}0.029 * \\
(0.016)\end{array}$ \\
\hline InfoeduQC2*Fachabi & & $\begin{array}{l}0.085^{* * *} \\
(0.031)\end{array}$ \\
\hline InfoeduQC2*Abitur & & $\begin{array}{l}0.112^{* * *} * \\
(0.026)\end{array}$ \\
\hline Constant & $\begin{array}{l}\text { 6.826*** } \\
(0.048)\end{array}$ & $\begin{array}{l}6.872 * * * \\
(0.048)\end{array}$ \\
\hline Adj. $R^{2}$ & 0.382 & 0.389 \\
\hline Observations & 12866 & 12328 \\
\hline $\begin{array}{l}\text { Note: Robust standard errc } \\
\text { fultime working men and e } \\
\text { definition of InfoeduQC } 1 \\
\text { groups are } 9 \text { years of sc } \\
\text { respective InfoeduQC var } \\
\text { regressions are } 24 \text { industry d } \\
\text { from the } 1991 / 1992 \text { and th } \\
\text { Career survey are pooled. } \\
\text { Statistical significance at the }\end{array}$ & $\begin{array}{l}\text { re reported in par } \\
\text { de those without an } \\
\text { InfoeduQC2 see te } \\
\text { ing (Hauptschule) } \\
\text { of the latter. } \\
\text { hes and controls for } \\
98 / 1999 \text { cross-secti } \\
(5 \%, 10 \%) \text { level de }\end{array}$ & $\begin{array}{l}\text { ses. We include only } \\
\text { ooling degree. For the } \\
\text { d Table 1. Reference } \\
\text { interactions with the } \\
\text { onal controls in the } \\
\text { b status. Observations } \\
\text { the Qualification and } \\
* * *(* * *) \text {. }\end{array}$ \\
\hline
\end{tabular}

Table A.2: OLS Estimates of the Returns to Informal Education 


\begin{tabular}{|c|c|c|c|c|c|c|c|c|}
\hline & \multicolumn{2}{|c|}{ INFOEDU1QC (yes=1) } & \multicolumn{2}{|c|}{ INFOEDU2QC (yes=1) } & \multicolumn{2}{|c|}{ INFOEDU3QC (yes=1) } & \multicolumn{2}{|c|}{ INFOEDU4QC $($ yes $=1)$} \\
\hline & (1) & (2) & (1) & (2) & (1) & (2) & (1) & (2) \\
\hline AGE & $\begin{array}{l}0.006^{* * *} \\
(0.001)\end{array}$ & $\begin{array}{l}0.005 * * * \\
(0.001)\end{array}$ & $\begin{array}{l}0.011 * * * \\
(0.002)\end{array}$ & $\begin{array}{l}0.008 * * * \\
(0.003)\end{array}$ & $\begin{array}{l}0.012 * * * \\
(0.003)\end{array}$ & $\begin{array}{l}0.008 * * \\
(0.004)\end{array}$ & $\begin{array}{l}0.011 * * \\
(0.005)\end{array}$ & $\begin{array}{l}-0.003 \\
(0.005)\end{array}$ \\
\hline $\operatorname{AGE}^{2}\left(\mathrm{x}^{1} 0^{-2}\right)$ & $\begin{array}{l}-0.006 * * * \\
(0.001)\end{array}$ & $\begin{array}{l}-0.005^{* * *} \\
(0.001)\end{array}$ & $\begin{array}{l}-0.011^{* * *} \\
(0.003)\end{array}$ & $\begin{array}{l}-0.008 * * \\
(0.003)\end{array}$ & $\begin{array}{l}-0.011 * * * \\
(0.004)\end{array}$ & $\begin{array}{l}-0.009 * * \\
(0.004)\end{array}$ & $\begin{array}{l}-0.009 * \\
(0.005)\end{array}$ & $\begin{array}{l}0.003 \\
(0.006)\end{array}$ \\
\hline $\mathrm{REAL}^{\circ}$ & $\begin{array}{l}0.015 \text { *** } \\
(0.003)\end{array}$ & $\begin{array}{l}0.017 \text { *** } \\
(0.003)\end{array}$ & $\begin{array}{l}0.034 * * * \\
(0.008)\end{array}$ & $\begin{array}{l}0.032 \text { *** } \\
(0.009)\end{array}$ & $\begin{array}{l}0.065 \text { *** } \\
(0.012)\end{array}$ & $\begin{array}{l}0.064 * * * \\
(0.013)\end{array}$ & $\begin{array}{l}0.052 \text { *** } \\
(0.017)\end{array}$ & $\begin{array}{l}0.037 * * \\
(0.018)\end{array}$ \\
\hline FACHABI $^{\circ}$ & $\begin{array}{l}0.025 * * * \\
(0.004)\end{array}$ & $\begin{array}{l}0.023 * * * \\
(0.004)\end{array}$ & $\begin{array}{l}0.095 * * * \\
(0.010)\end{array}$ & $\begin{array}{l}0.080 * * * \\
(0.012)\end{array}$ & $\begin{array}{l}0.127 * * * \\
(0.017)\end{array}$ & $\begin{array}{l}0.118 * * * \\
(0.019)\end{array}$ & $\begin{array}{l}0.144 * * * \\
(0.022)\end{array}$ & $\begin{array}{l}0.108 * * * \\
(0.024)\end{array}$ \\
\hline ABITUR $^{\circ}$ & $\begin{array}{l}0.023 * * * \\
(0.005)\end{array}$ & $\begin{array}{l}0.021 * * * \\
(0.005)\end{array}$ & $\begin{array}{l}0.088 * * * \\
(0.011)\end{array}$ & $\begin{array}{l}0.082 * * * \\
(0.012)\end{array}$ & $\begin{array}{l}0.153 \text { *** } \\
(0.016)\end{array}$ & $\begin{array}{l}0.154 * * * \\
(0.018)\end{array}$ & $\begin{array}{l}0.172 * * * \\
(0.022)\end{array}$ & $\begin{array}{l}0.151 * * * \\
(0.023)\end{array}$ \\
\hline SHIFT $^{\circ}$ & $\begin{array}{l}-0.020 * * * \\
(0.004)\end{array}$ & $\begin{array}{l}-0.022 * * * \\
(0.005)\end{array}$ & $\begin{array}{l}-0.072 * * * \\
(0.011)\end{array}$ & $\begin{array}{l}-0.072 * * * \\
(0.012)\end{array}$ & $\begin{array}{l}-0.045 * * * \\
(0.014)\end{array}$ & $\begin{array}{l}-0.050 \text { **** } \\
(0.015)\end{array}$ & $\begin{array}{l}-0.041 * * \\
(0.020)\end{array}$ & $\begin{array}{l}-0.047 * * \\
(0.021)\end{array}$ \\
\hline NIGHTSHIFT $^{\circ}$ & $\begin{array}{l}0.020 * * * \\
(0.003)\end{array}$ & $\begin{array}{l}0.019 \text { *** } \\
(0.003)\end{array}$ & $\begin{array}{l}0.022 * * \\
(0.009)\end{array}$ & $\begin{array}{l}0.014 \\
(0.010)\end{array}$ & $\begin{array}{l}0.013 \\
(0.013)\end{array}$ & $\begin{array}{l}0.010 \\
(0.014)\end{array}$ & $\begin{array}{l}-0.023 \\
(0.017)\end{array}$ & $\begin{array}{l}-0.022 \\
(0.018)\end{array}$ \\
\hline $\mathrm{URBAN}^{\circ}$ & $\begin{array}{l}-0.005 \\
(0.003)\end{array}$ & $\begin{array}{l}-0.005 \\
(0.003)\end{array}$ & $\begin{array}{l}-0.031 * * * \\
(0.009)\end{array}$ & $\begin{array}{l}-0.033 * * * \\
(0.009)\end{array}$ & $\begin{array}{l}-0.013 \\
(0.011)\end{array}$ & $\begin{array}{l}-0.016 \\
(0.012)\end{array}$ & $\begin{array}{l}-0.027 * \\
(0.015)\end{array}$ & $\begin{array}{l}-0.036 * * \\
(0.016)\end{array}$ \\
\hline SEMIURBAN $^{\circ}$ & $\begin{array}{l}-0.001 \\
(0.003)\end{array}$ & $\begin{array}{l}-0.003 \\
(0.003)\end{array}$ & $\begin{array}{l}-0.006 \\
(0.009)\end{array}$ & $\begin{array}{l}-0.014 \\
(0.009)\end{array}$ & $\begin{array}{l}-0.006 \\
(0.012)\end{array}$ & $\begin{array}{l}-0.014 \\
(0.013)\end{array}$ & $\begin{array}{l}-0.052 * * * \\
(0.016)\end{array}$ & $\begin{array}{l}-0.070^{* * * *} \\
(0.017)\end{array}$ \\
\hline LOGWAGE & & $\begin{array}{l}0.028 * * * \\
(0.005)\end{array}$ & & $\begin{array}{l}0.110 * * * \\
(0.012)\end{array}$ & & $\begin{array}{l}0.116 * * * \\
(0.017)\end{array}$ & & $\begin{array}{l}0.208 * * * \\
(0.023)\end{array}$ \\
\hline Likelihood & -2806.66 & -2527.55 & -5692.14 & -4966.70 & -7863.65 & -6774.39 & -4869.62 & -4095.90 \\
\hline Pseudo- $\mathrm{R}^{2}$ & 0.189 & 0.196 & 0.165 & 0.173 & 0.099 & 0.110 & 0.132 & 0.152 \\
\hline $\mathrm{N}$ & 12815 & 11190 & 12736 & 11104 & 12738 & 11105 & 8107 & 6979 \\
\hline
\end{tabular}

Notes: Marginal effects for fulltime working men in West Germany. Robust standard errors are reported in parentheses. We drop those without any schooling education. For the definition of the dependent variables see text and Table 1 . Reference groups are 9 years of schooling (Hauptschule), normal work schedule, living in rural area. Additional controls included in the regressions are controls for the job status and dummies for the two digit occupational group. Observations from the 1991/1992 and the 1998/1999 cross-section of the Qualification and Career survey are pooled. The models with INFOEDU4QC are estimated only with the 1998/99 cross-section. The variable LOGWAGE reports the logarithm of gross monthly earnings deflated in terms of 1995

Statistical significance at the $1 \%(5 \%, 10 \%)$ level denoted $* * *(* * *)$

${ }^{\circ}$ For this variables we report the marginal effect for a discrete change of the dummy variable from 0 to 1.

Table A.3: Determinants of Participating in Informal Education Within the Last Five Years (Q and C Data, Logit Models, Marginal Effects) 


\begin{tabular}{l|l}
\hline MINING & 0.322 \\
& $(0.059)$ \\
\hline CHEMIND & 0.268 \\
& $(0.049)$ \\
\hline METAL & 0.318 \\
& $(0.048)$ \\
\hline MACHINE & 0.331 \\
& $(0.047)$ \\
\hline ELECTRO & 0.334 \\
& $(0.052)$ \\
\hline TEXTILE & 0.232 \\
& $(0.051)$ \\
\hline FOOD* & 0.090 \\
& $(0.060)$ \\
\hline CONSTRUC & 0.283 \\
& $(0.047)$ \\
\hline TRADE* & 0.104 \\
& $(0.047)$ \\
\hline SERVICE & 0.251 \\
& $(0.047)$ \\
\hline OTHER & 0.181 \\
& $(0.049)$ \\
\hline SELFEMPL & -0.270 \\
& $(0.039)$ \\
\hline WHITCOLL & -0.100 \\
& $(0.028)$ \\
\hline BLUECOLL & -0.266 \\
& $(0.032)$ \\
\hline REAL & 0.103 \\
& $(0.022)$ \\
\hline FACHABI & 0.212 \\
& $(0.035)$ \\
\hline ABITUR & 0.306 \\
& $(0.026)$ \\
\hline AGE & 0.037 \\
& $(0.006)$ \\
\hline AGESQ (x 10') & -0.037 \\
& $(0.007)$ \\
\hline Constant & 1.814 \\
& $(0.121)$ \\
\hline R $^{2}$ & 0.313 \\
\hline $\mathrm{N}$ & 1933 \\
\hline Note: Standard errors in parentheses. All variables except those marked \\
with *are significant at the one-percent level. Reference groups: \\
AGRICUL, CIVILSER, HAUPT. & \\
& \\
\hline
\end{tabular}

Table A.4: OLS Regression with the I-Wave of the German Socio-Economic Panel and the net hourly wage as the dependent variable (for fulltime working men) 


\section{B Data Description}

\section{B.1 Time Use Data}

Our main data source is a sub-sample of the Scientific Use File 95\% sample of the German Time Use Data 1991/1992. This data set was collected by the German Federal Statistical Office and provides very detailed information concerning the time use of about 7200 German households. All household members older than 12 years were asked to keep diaries for two consecutive days reporting their activities in plain text in five-minute intervals. The data collection was spread over an entire year to take differences in time use during different seasons of the year into account. The activities reported in the diaries were coded into 231 categories of time use by the Federal Statistical Office. In addition, the Time Use study gives detailed information on the socio-economic background of all household members by providing the information from a questionnaire which was completed with the help of an interviewer for each household.

\section{B.2 Qualification and Career Survey data}

Our second data source are the 1991/1992 and the 1998/1999 cross-sections of the Qualification and Career Survey data (Q and C data) of the Federal Institute for Vocational Research (BiBB) and the German Institute for Employment Research (IAB). In this survey, a representative 0.1 percent sample of the German working population is asked about their qualifications, job career, workplace conditions and job satisfaction. Questions about participation in different activities of formal and informal (occupation related) education within the period of five years prior to the date of the survey are of particular interest in our context. For our analysis, we pool the observations from the 1991/1992 and the 1998/1999 cross-sections. This is possible because the questions of interest for our study are identical in both cross-

sections. To make the wage information comparable, we deflate wages in terms of 1995 wages using official consumer price index information.

\section{Predicting a Wage Rate with GSOEP Data}

The wage rate in the GSOEP (see Wagner, Burkhauser, and Behringer (1993) for details about this data set) is constructed by dividing the reported gross monthly income by 4.3 times the maximum of the actual and contractual hours worked per week. This method is employed following Haisken-DeNew and Schmidt (1999) to take account of the self-employed in the data set and to get a correct measure for people who work less hours than normally in the interview week.

We estimate a wage equation which includes controls for age, educational degree, job status and industry, where we take care to ensure that the definitions of variables are the same in the GSOEP and the time use data. The predicted wage is identified in the subsequent time use equation by the industry dummies. The approach to include industry dummies as explanatory variables in the wage equation follows the the extensive literature on inter-industry wage differentials starting with the seminal paper by Krueger and Summers (1988) and shown to be valid for Germany by Haisken-DeNew and Schmidt (1997, 1999). 


\section{Not intended for publication}

\section{Mathematical Appendix}

For the ease of presentation in the following the variable $Z$ is substituted by the function $f(\cdot)$

$$
Z=\frac{\left(W_{1}+W_{2} T_{I} \eta\right)\left(T^{*}-T_{I}\right)+V}{a P+b W_{m}}=f\left(T_{I}, V, W_{1}, W_{2}, \eta\right)
$$

This equation turns simply out of Equation (7) by substituting $b Z$ for $T_{Z}$. Some steps in the following analysis make use of the function $f(\cdot)$ as

$$
Z=\frac{\left(W_{1}+W_{2} T_{I} \eta\right)\left(T^{*}-T_{I}-T_{Z}\right)+V}{a P}=f^{u s}\left(T_{I}, V, W_{1}, W_{2}, \eta\right) .
$$

The reader should keep in mind that $f(\cdot)$ and $f^{u s}(\cdot)$ are effectively the same functions, they differ only in the above mentioned substitution for $T_{Z}$. The difference is made to make it easier to follow the algebraic manipulations in the calculations below.

The derivative with respect to the variable of interest is given by the chain rule implicitly as

$$
\begin{aligned}
\frac{\partial}{\partial \chi}\left(\frac{\partial}{\partial T_{I}} U\left(f\left(T_{I}, \chi\right) ; \eta T_{I}, \chi\right)\right)= & \frac{\partial}{\partial^{2} T_{I}^{2}} U\left(f\left(T_{I}, \chi\right) ; \eta T_{I}, \chi\right) \frac{\partial T_{I}}{\partial \chi} \\
& +\frac{\partial}{\partial \chi} \frac{\partial}{\partial T_{I}} U\left(f\left(T_{I}, \chi\right) ; \eta T_{I}, \chi\right) \\
= & 0
\end{aligned}
$$

where $\quad \chi=V, W_{1}, W_{2} \quad$ are our variables of interest.

From this equation it is easy to derive the change in informal education for a marginal change in our variable of interest by

$$
\begin{gathered}
\frac{\partial T_{I}}{\partial \chi}=-\frac{\partial}{\partial \chi} \frac{\partial}{\partial T_{I}} U\left(f\left(T_{I}, \chi\right) ; \eta T_{I}, \chi\right) \cdot \frac{1}{D^{2}} . \\
\text { where } \quad D^{2}=\frac{\partial}{\partial^{2} T_{I}^{2}} U\left(f\left(T_{I}, \chi\right) ; \eta T_{I}, \chi\right)
\end{gathered}
$$

By assumption $D^{2}$ is negative, which means it is sufficient to find out the sign of the first term on the right hand side in Equation (A1 ) to determine the direction of the change in productive leisure by a change in $\chi$. According to Young's theorem one can calculate $\frac{\partial}{\partial T_{I}} \frac{\partial}{\partial \chi} U\left(f\left(T_{I}, \chi\right) ; \eta T_{I}, \chi\right)$ instead of $\frac{\partial}{\partial \chi} \frac{\partial}{\partial T_{I}} U\left(f\left(T_{I}, \chi\right) ; \eta T_{I}, \chi\right)$ as long as the partial derivatives are well-behaved, what is assumed. 


\section{D.1 Comparative Statics with respect to $V$}

In order to determine the effect on informal education of a change in other household income calculate $\frac{\partial}{\partial T_{I}} \frac{\partial}{\partial V} U\left(f\left(T_{I}, V\right) ; \eta T_{I}, V\right)$.

In a first step keep $T_{I}$ fixed as the optimal $T_{I}^{*}$.

$$
\begin{aligned}
\frac{\partial}{\partial V} U\left(f\left(T_{I}^{*}, V\right) ; T_{I}^{*}, I\right) & =U_{1} \cdot \frac{\partial}{\partial V} f\left(T_{I}^{*}, V\right) \\
& =\frac{U_{1}}{a P+b W_{m}}
\end{aligned}
$$

Now one can solve

$$
\begin{array}{r}
\frac{\partial}{\partial T_{I}} \frac{\partial}{\partial V} U\left(f\left(T_{I}, V\right) ; \eta T_{I}, V\right)=\frac{\partial}{\partial T_{I}} \frac{U_{1}\left(f^{u s}\left(T_{I}\right), \eta T_{I}\right)}{a P+b W_{m}} \\
=\frac{\frac{\partial}{\partial T_{I}}\left[U_{1}\left(f^{u s}\left(T_{I}\right), \eta T_{I}\right)\right] \cdot\left(a P+b W_{m}\right)-U_{1}\left(f^{u s}\left(T_{I}\right), \eta T_{I}\right) b W_{2} \eta}{\left(a P+b W_{m}\right)^{2}} \\
=\frac{1}{\left(a P+b W_{m}\right)^{2}}\left[\left(a P+W_{m}\right)\left(U_{11} \cdot \frac{\partial}{\partial T_{I}} f^{u s}\left(T_{I}\right)+U_{12} \eta\right)-U_{1} b W_{2} \eta\right] .
\end{array}
$$

Note that here the absolutely equivalent $f^{u s}(\cdot)$ is substituted for $f(\cdot) . f^{u s}(\cdot)$ is written as a function of $T_{I}$ only as a matter of presentation. After solving $\frac{\partial}{\partial T_{I}} f^{u s}\left(T_{I}\right)$ one gets

$$
\begin{aligned}
\frac{\partial}{\partial T_{I}} \frac{\partial}{\partial I} U\left(f\left(T_{I}\right), T_{I}\right)= & {\left[-\frac{\left(a P+b W_{m}\right)}{a P} U_{11}\left(W_{1}+W_{2}\left(T_{I}-T_{W}\right) \eta\right)\right.} \\
& +U_{12}\left(a P+b W_{m}\right) \eta \\
& \left.-U_{1} b W_{2} \eta\right] \frac{1}{\left(a P+b W_{m}\right)^{2}}
\end{aligned}
$$

Substituting this equation in the general equation (A1) gives equation (9).

\section{D.2 Comparative Statics with respect to $W_{1}$}

To determine the effect on time spent on informal education of a change in the wage parameter $W_{1}$ calculate $\frac{\partial}{\partial T_{I}} \frac{\partial}{\partial W_{1}} U\left(f\left(T_{I}, W_{1}\right) ; \eta T_{I}, W_{1}\right)$.

Again keep first $T_{I}$ fixed as the optimal $T_{I}^{*}$

$$
\begin{aligned}
\frac{\partial}{\partial W_{1}} U\left(f^{u s}\left(T_{I}^{*}, W_{1}\right) ; \eta T_{I}^{*}, W_{1}\right) & =U_{1} \cdot \frac{\partial}{\partial W_{1}} f^{u s}\left(T_{I}^{*}, W_{1}\right) \\
& =U_{1} \frac{T_{W}}{a P}
\end{aligned}
$$

to solve in a second step

$$
\frac{\partial}{\partial T_{I}}\left(\frac{U_{1}}{\left(a P+b W_{m}\right)} \cdot \frac{\left(a P+b W_{m}\right) T_{W}}{a P}\right)
$$


which results by applying the chain rule in the following equation

$=\frac{a P+b W_{m}}{a P} \cdot T_{W} \cdot \frac{\partial}{\partial T_{I}}\left(\frac{U_{1}}{a P+b W_{m}}\right)+\frac{U_{1}}{a P+b W_{m}} \cdot \frac{\partial}{\partial T_{I}} \frac{\left(a P+b W_{m}\right) T_{W}}{a P}$.

The first part here is the result for the comparative statics with respect to $I$ from Equation (A4), so we get

$$
\begin{aligned}
= & \frac{a P+b W_{m}}{a P} \cdot T_{W} \cdot \frac{\partial}{\partial T_{I}} \frac{\partial}{\partial V} U\left(f\left(T_{I}\right), \eta T_{I}\right) \\
& +\frac{U_{1}}{a P+b W_{m}} \cdot \frac{-a P-b W_{1}-2 b W_{2} T_{I} \eta+b W_{2} T^{*} \eta-b W_{2} T_{Z} \eta}{a P} \\
= & \frac{a P+b W_{m}}{a P} \cdot T_{W} \cdot \frac{\partial}{\partial T_{I}} \frac{\partial}{\partial V} U\left(f\left(T_{I}\right), \eta T_{I}\right)-\frac{U_{1}}{a P+b W_{m}} \cdot \frac{a P+b\left(W_{1}+W_{2}\left(T_{I}-T_{W}\right) \eta\right)}{a P} \\
& \text { now substitute the first order condition } \\
= & \frac{a P+b W_{m}}{a P} \cdot T_{W} \cdot \frac{\partial}{\partial T_{I}} \frac{\partial}{\partial V} U\left(f\left(T_{I}\right), \eta T_{I}\right)-\frac{U_{1}}{a P+b W_{m}} \cdot \frac{a P+b\left(\frac{U_{2}\left(a P+b W_{m}\right) \eta}{U_{1}}\right)}{a P} \\
= & \frac{a P+b W_{m}}{a P} \cdot T_{W} \cdot \frac{\partial}{\partial T_{I}} \frac{\partial}{\partial V} U\left(f\left(T_{I}\right), \eta T_{I}\right)-\frac{U_{1}}{a P+b W_{m}} \cdot \frac{a P U_{1}+b U_{2}\left(a P+b W_{m}\right) \eta}{a P U_{1}} \\
= & \frac{a P+b W_{m}}{a P} \cdot T_{W} \cdot \frac{\partial}{\partial T_{I}} \frac{\partial}{\partial V} U\left(f\left(T_{I}\right), \eta T_{I}\right) \\
& -\frac{1}{a P\left(a P+b W_{m}\right)} \cdot\left[a P U_{1}+b U_{2}\left(a P+b W_{m}\right) \eta\right]
\end{aligned}
$$

which can be substituted in the general Equation (A1 ) to get Equation (10).

\section{D.3 Comparative Statics with respect to $W_{2}$}

To determine the effect on time spent on informal education of a change in the wage parameter $W_{2}$ calculate $\frac{\partial}{\partial T_{I}} \frac{\partial}{\partial W_{2}} U\left(f\left(T_{I}, W_{2}\right) ; \eta T_{I}, W_{2}\right)$.

Keep first $T_{I}$ fixed as the optimal $T_{I}^{*}$

$$
\begin{aligned}
\frac{\partial}{\partial W_{2}} U\left(f^{u s}\left(T_{I}^{*}, W_{2}\right) ; \eta T_{I}^{*}, W_{2}\right) & =U_{1} \cdot \frac{\partial}{\partial W_{2}} f^{u s}\left(T_{I}^{*}, W_{2}\right) \\
& =U_{1} \frac{\eta T_{I} T_{W}}{a P}
\end{aligned}
$$

to solve in a second step

$$
\frac{\partial}{\partial T_{I}}\left(\frac{U_{1}}{\left(a P+b W_{m}\right)} \cdot \frac{\left(a P+b W_{m}\right) \eta T_{I} T_{W}}{a P}\right)
$$

which results in 


$$
\begin{aligned}
= & \frac{a P+b W_{m}}{a P} \cdot \eta T_{I} T_{W} \cdot \frac{\partial}{\partial T_{I}}\left(\frac{U_{1}}{a P+b W_{m}}\right)+\frac{U_{1}}{a P+b W_{m}} \cdot \frac{\partial}{\partial T_{I}}\left(\frac{\left(a P+b W_{m}\right) \eta T_{I} T_{W}}{a P}\right) \\
= & \frac{a P+b W_{m}}{a P} \cdot \eta T_{I} T_{W} \cdot \frac{\partial}{\partial T_{I}}\left(\frac{U_{1}}{a P+b W_{m}}\right) \\
& +\frac{U_{1}}{a P+b W_{m}} \cdot\left(\frac{\frac{\partial}{\partial T_{I}}\left(a P+b W_{m}\right) \cdot \eta T_{W} T_{I}+\left(a P+b W_{m}\right) \eta T_{W}}{a P}\right) \\
= & \eta T_{I} \cdot\left[\frac{a P+b W_{m}}{a P} \cdot T_{W} \cdot \frac{\partial}{\partial T_{I}}\left(\frac{U_{1}}{a P+b W_{m}}\right)+\frac{U_{1}}{a P+b W_{m}} \cdot \frac{\partial}{\partial T_{I}}\left(\frac{\left(a P+b W_{m}\right) T_{W}}{a P}\right)\right] \\
& +\frac{U_{1}}{a P+b W_{m}} \cdot \frac{\left(a P+b W_{m}\right) \eta T_{W}}{a P}
\end{aligned}
$$

The square bracket is now exactly what we calculated in Equation (A6 ) to determine the effect of the first wage parameter on time spent on informal education. So we end up after substituting with

$$
\frac{\partial}{\partial T_{I}} \frac{\partial}{\partial W_{2}} U\left(f\left(T_{I}\right), \eta T_{I}\right)=\eta T_{I} \frac{\partial}{\partial T_{I}} \frac{\partial}{\partial W_{1}} U\left(f\left(T_{I}\right), \eta T_{I}\right)+\frac{1}{a P} U_{1} \eta T_{W}
$$

which can be substituted in the general Equation (A1 ) to obtain Equation (11). 


\section{IZA Discussion Papers}

\begin{tabular}{|c|c|c|c|c|}
\hline No. & Author(s) & Title & Area & Date \\
\hline 845 & $\begin{array}{l}\text { G. Dewit } \\
\text { H. Görg } \\
\text { C. Montagna }\end{array}$ & $\begin{array}{l}\text { Should I Stay or Should I Go? A Note on } \\
\text { Employment Protection, Domestic Anchorage, } \\
\text { and FDI }\end{array}$ & 2 & $08 / 03$ \\
\hline 846 & $\begin{array}{l}\text { D. de la Croix } \\
\text { F. Docquier }\end{array}$ & $\begin{array}{l}\text { Diverging Patterns of Education Premium and } \\
\text { School Attendance in France and the US: A } \\
\text { Walrasian View }\end{array}$ & 6 & $08 / 03$ \\
\hline 847 & B. R. Chiswick & $\begin{array}{l}\text { Jacob Mincer, Experience and the Distribution of } \\
\text { Earnings }\end{array}$ & 1 & $08 / 03$ \\
\hline 848 & $\begin{array}{l}\text { A. Chevalier } \\
\text { G. Conlon }\end{array}$ & Does It Pay to Attend a Prestigious University? & 6 & 08/03 \\
\hline 849 & W. Schnedler & Traits, Imitation, and Evolutionary Dynamics & 5 & $08 / 03$ \\
\hline 850 & $\begin{array}{l}\text { S. P. Jenkins } \\
\text { L. Osberg }\end{array}$ & $\begin{array}{l}\text { Nobody to Play with? The Implications of } \\
\text { Leisure Coordination }\end{array}$ & 5 & $08 / 03$ \\
\hline 851 & J. D. Angrist & $\begin{array}{l}\text { Treatment Effect Heterogeneity in Theory and } \\
\text { Practice }\end{array}$ & 6 & $08 / 03$ \\
\hline 852 & $\begin{array}{l}\text { A. Kugler } \\
\text { M. Kugler }\end{array}$ & $\begin{array}{l}\text { The Labor Market Effects of Payroll Taxes in a } \\
\text { Middle-Income Country: Evidence from } \\
\text { Colombia }\end{array}$ & 1 & $08 / 03$ \\
\hline 853 & $\begin{array}{l}\text { I. Ekeland } \\
\text { J. J. Heckman } \\
\text { L. Nesheim }\end{array}$ & Identification and Estimation of Hedonic Models & 6 & 08/03 \\
\hline 854 & $\begin{array}{l}\text { A. Ferrer-i-Carbonell } \\
\text { B. M. S. Van Praag }\end{array}$ & Income Satisfaction Inequality and Its Causes & 3 & $08 / 03$ \\
\hline 855 & $\begin{array}{l}\text { B. Irlenbusch } \\
\text { D. Sliwka }\end{array}$ & $\begin{array}{l}\text { Career Concerns in a Simple Experimental } \\
\text { Labour Market }\end{array}$ & 1 & $08 / 03$ \\
\hline 856 & D. Sliwka & $\begin{array}{l}\text { Management Incentives, Signaling Effects and } \\
\text { the Costs of Vertical Integration }\end{array}$ & 1 & $08 / 03$ \\
\hline 857 & $\begin{array}{l}\text { M. Francesconi } \\
\text { A. Muthoo }\end{array}$ & An Economic Model of Child Custody & 3 & $08 / 03$ \\
\hline 858 & C. U. Chiswick & $\begin{array}{l}\text { History of Historical Statistics of the United } \\
\text { States }\end{array}$ & 7 & $08 / 03$ \\
\hline 859 & R. Fahr & $\begin{array}{l}\text { Loafing or Learning? The Demand for Informal } \\
\text { Education }\end{array}$ & 5 & $08 / 03$ \\
\hline
\end{tabular}

An updated list of IZA Discussion Papers is available on the center's homepage www.iza.org. 